\title{
MASJID NURUL HUD A; LAHIRNYA KESEPAKATAN WARGA BONE-BONE BERHENTIMEROKOK Nurul Huda Mosque: The Emergence of Among Bone-Bone Community to Stop Smoking
}

\author{
Oleh: Mappeaty Nyorong* \\ * Staf Pengajar Bagian Promosi Kesehatan dan Ilmu Perilaku \\ Fakultas Kesehatan Masyarakat Universitas Hasanuddin Makassar \\ Kampus Tamalanrea Makassar \\ E-mail: nmappeaty@vahoo.com
}

\begin{abstract}
Abstrak
Studi ini didasarkan bahwa sesuatu yang dipelajari dan disosialisasikan sejak usia dini akan sulit untuk diabah, tetapi warga desa Bone-Bone yang diketahui beberapa waktu berselang sebagian warganya merokok, kemudian mereka mampu berhenti secara keseluruhan warganya.

Tnjuan studi ini adalah (1) menganalisis fungsi masj id Nurul Huda sebagai tempat penyebaran kesepakatan berhenti merokok, dan (2) bagaimana memengaruhi perokok berhenti merokok.

Metode penelitian yang digunakan adalah metode kualitatif. Data diperoleh melalui (1) interview, (2) diskusi kelompok terarah, dan (3) observasi. Ditemukan bahwa tokoh masyarakat dan agama yang memengaruhi warga yang merokok berhenti melakukannya, dan menggunakan masjid sebagai basis "Bone-Bone Bebas Asap Rokok".
\end{abstract}

Keywords: Kesepakatan di Masjid, Perubahan Perilaku

\section{Abstract}

This study is based on the assumption that something is learned and socializedfrom an early age would be difficult to change, but the people in Bone-Bone Village the first part of its citizens are smoking in afew years then they were able to quit smoking as a whole.

The purpose of this study is to (1) analyze the function of the Nurul Huda mosque as place of dissemination of stop smoking commitment; and (2) how to influence the smokers to quit smoking.

The research method used was qualitative research. Data were collected through (1) interviews, (2) focus group discussion and (3) observation. It was found that the community and religious leaders influencing the smokers to quit smoking by using mosque as a base of Bone-Bone smokeless village.

Keywords: the role of mosque in changing behavior.

\section{PENDAHULUA N}

$\mathrm{O}$

rang merokok tampaknya adalah bagian yang penting dalam kehidupan bermasyarakat. Rokok dalam budaya Indonesia dapat dijumpai atau ditawarkan pada saat pesta, kenduri, atau rr.enemukan teman yang baru saja dikenal, atau malah c.anggap sebagai kalimat awal dalam memulai pembicaraan dengan menawarkan sebatang rokok, sambil mengeluarkan setengah rokok dari bungkusnya n berkata "Ayo, rokok."

Dalam hidup sehari-hari, fakta mengungkapkan tesuai dengan kajian dalam ilmu-ilmu sosial kemasyarakatan, terutama kaj ian yang sifatnya antropologis bahwa sesuatu yang dipelajari, dibiasakan dalam kehidupan sehari-hari akan menjadi gaya hidup, keadaan demikian sulit diubah. Namun, ditemukan dalam suatu wilayah pemukiman, terdapat kebiasaan merokok, dapat berhenti kebiasaan itu dalam waktu relatif singkat. Inilah yang menarik perhatian peneliti, ingin menelusuri lebih dalam tentanghal itu.

Dusun yang namanya Bone-Bone, di lain pihak, untuk beberapa waktu dahulu adalah kampung yang status pemerintahannya disebut dusun yang diberi nama dusun Bone-Bone, kemudian ditingkatkan statusnya menjadi sebuah desa pada tahun 2007, yang beberapa

Jurnal "Al-Qalam" Volume 1 Nomor 1 Januari - Juni 2011

ksi naskah ! tanggal 10 Maret 2011. Koreksi naskah It tanggal 12 April 2011. Finalisasi Waskah 22 Juni 2011 
tahun lalu masyarakatnya sebagian juga adalah perokok, malah dijumpai beberapa orang di antaranya yang mengaku bahwa mereka merokok sejak usia dini. Namun, sejak tahun 2000 seorang inovator, kepala dusun, kemudian diangkat sebagai kepala desa yang menggagas dusunnya, "dusun bebas asap rokok." Ia dibantu oleh orang-orang yang sejalan dengan pikirannya, tokoh masyarakat lain dan tokoh agama yang memomulerkan gagasan itu dan berhasil. Hingga saat ini desa Bone-Bone bebas asap rokok

Masalah pokok penelitian ini adalah bagaimana peranan masjid Nurul Huda sebagai tempat mengumumkan kesepakatan "Bone-Bone bebas asap rokok"? Dan bagaimana memengaruhi perokok berhenti merokok? Sedangkan tujuan penelitian ini adalah untuk menjawab penelitian di atas. Kegunaannya adalah sebagai masukan bagi banyak Pemerintah Daerah Kabupaten maupun Kota yang sedang giat-giatnya mencari kiat mengurangi konsumsi rokok warganya hingga menghentikan kebiasaan merokok.

\section{TINJAUAN PUSTAKA}

Penelitian ini mempekerjakan teori interaksionisme simbolik sebagai teori utama (Grand Theory) seperti yang tertuang dalam kerangka Herbert Blumer, Dalam mempelajari interaksi sosial digunakan pendekatan interaksi tertentu, yang dikenal dengan interactionist perspective. Salah satu di antara pendekatan itu adalah interaksionisme simbolik (symbolic interactionism).

Menurut Henslin penganut interaksionisme simbolik mempelajari bagaimana orang menggunakan simbol untuk mengembangkan dan berbagi pandangan mereka mengenai dunia dan untuk saling berkomunikasi ${ }^{2}$. Para penganut interaksionisme simbolik, menurut Ritzer dan Goodman, biasanya memusatkan perhatiannya pada jenjang mikro-pada interaksi berskala kecil, tatap muka. Pendekatan ini bersumber dari pemikiran George Herbert Mead ${ }^{3}$. Pendekatan interaksionisme simbolik terfokus pada sasaran interaksi sosial: di dalam interaksi itu muncul berbagai simbol yang punya makna dan memerlukan penafsiran.

\section{Teori Medan Kurt Lewin}

Kurt Lewin (dalam Ross and Mico), menggagas teori medan dengan menyatakan bahwa perilaku manusia adalah suatu keadaan yang seimbang antara kekuatan-kekuatan pendorong (driving forces) dan kekuatan-kekuatan penahan (restraining forces). Jadi diperlukan 3 cara mengefektifkan perubahan perilaku:

1. memperkuat "driving forces" dengan menggalakkan pendidikan, penyuluhan, bahkan peraturan dan perundang-undangan.

2. mereduksi "restraining forces" dengan cara mengikut sertakan masyarakat dalam memecahkan masalah-masalah sendiri. Dengan ikut sertanya masyarakat dalam kegiatan pemecahan masalah akan dapat mengurangi kekuatankekuatan penahan yang ada pada diri mereka.

3. kombinasi keduanya, dengan melakukan pendidikan, melalui penyuluhan, khotbah, ceramah agama, di samping itu juga melibatkan warga masyarakat dalam upaya mengatasi masalah merokok mereka."

\section{Komunikasi, perubahan sosial dan perilaku}

Saluran-saluran komunikasi bagi masyarakat pedesaan, meliputi (1) penggunaan media massa, (2) penggunaan komunikasi interpersonal dan (3) penggunaan media forum. Dalam penggunaan media massa, menurut Rogers (dalam Abustam, 1984) saluran-saluran komunikasi adalah cara bagaimana pesan itu bergerak dari sumber ke penerima. Saluran itu merupakan sarana untuk menerima pesan dari seseorang atau lembaga. Selain itu, saluran

Ritzer, G. dan Goodman, D. J., 2003. Modern Sociological Theory. Edisi Keenam. Terjemahan oleh Alimandan. 2007. Jakarta: Kencana Prenada Media Group

Henslin, James M. 2006. Essentials of Sosiologi: A Down-to-Earth Approach. Jilid 1. Edisi 6. Terjemahan oleh Kamanto Sunarto. 2007. Jakarta: Penerbit Erlangga.

Ritzer, G. dan Goodman, D. J., 2003. Modern Sociological Theory. Edisi Keenam. Terjemahan oleh Alimandan. 2007. Jakarta: Kencana Prenada Media Group

Ross, Helen S., and Mico, Paul R., 1980. Theory and Practice in Health Education. California: Mayfield Publishing Company. 
komunikasi dapat pula berarti strategi, kalau sumber, pesan dan penerimanya sudah tertefttu. Penggunaan komunikasi interpersonal adalah saluran yang melibatkan pertemuan tatap-muka antara dua orang atau lebih, misalnya antara sumber dan penerima.

Saluran interpersonal, menurut Havelock efektif di dalam melakukan perubahan atas sikap yang melekat kuat pada diri anggota masyarakat. Arus pesan cenderung dua arah "two-way transmission processes, di mana umpan balik terjadi. Sedangkan penggunan media forum adalah penggabungan antara saluran komunikasi media massa dengan saluran komunikasi interpersonal merupakan cara yang sangat effektif dalam memperkenalkan ideaidea baru dan memengaruhi masyarakat agar menggunakan idea-idea tersebut.

Komunikasi dan perubahan sosial dalam Rogers digambarkan model komunikasi S-M-C-R-. FaktorFaktor komunikasi meliputi suatu pesan (M) yang diberikan kepada seseorang (R) melalui saluran komunikasi (C) dari seseorang yang bertindak sebagai (S). Penerimaan pesan itu mengakibatkan berubahnya perilaku merokok menjadi berhenti merokok.

$$
\begin{aligned}
& \text { 1. Sumber } \\
& \text { 2. Pesan } \\
& \text { 3. Saluran } \\
& \text { 4. Penerima, kemudian ditambahkan } \\
& \text { 5. Akibat komunikasi, }
\end{aligned}
$$

Bagaimana proses komunikasi yang mampu memengaruhi individu menggunakan, mempertahankan, atau menghindari perilaku tertentu, tergantung pada kuatnya informasi yang didapat oleh penerima. Meskipun juga disadari bahwa masih terdapat faktor-faktor lain yang dapat berperan dalam mengubah perilaku individu. Rogers (1983:24) menemukan hasil dari komunikasi terdapat lima kategori adopter:

$$
\begin{aligned}
& \text { 1. Inovator } \\
& \text { 2. Adopter pemula }
\end{aligned}
$$

3. Mayoritas awal

4. Mayoritas akhir

5. Laggard, yang paling lambat. ${ }^{6}$

\section{Perilaku kolektif}

Dalam hidup sehari-hari terlihat perilaku yang umum dilakukan oleh orang secara bersama-sama, melakukan hal yang sama, dan tidak tergantung pada apakah hal itu positifatau negatif. Individu melakukan sesuatu, yang jika dilakukan secara bersama-sama menjadi tindakan sosial. Kajian Parsons dkk. berpendapat bahwa komponen utama tindakan sosial adalah: (1) nilai-nilai, atau sumber umum legitimasi, (2) norma-norma, atau aturan baku dalam berinteraksi, (3) mobilisasi motivasi individu untuk tindakan yang terorganisasi dalam peran dan kolektivitas, dan (4) fasilitas situasional, atau keterampilan informasi, alatalat, dan hambatan di dalam mengejar tujuan yangjelas. menyusun klasifikasi perilaku kolektif termasuk adanya (1) gerakan orientasi-nilai, (2) gerakan orientasi-norma, (3) rasa bermusuhan, dan (4) kemudian gila dan panik. Dengan cara pendekatan nilai-tambah Smelser lebih jauh menjelaskan bahwa terdapat (1) kecocokan struktural, meskipun tidak seharusnya, (2) ketegangan, (3) tumbuhnya kepercayaan umum dan (4) kontrol sosial?.

Ahli sosiologi telah menekankan faktor budaya di dalam menganalisis perilaku, dan kurang menekankan aspek interaksi di antara orang-orang. Kecenderungan ini telah teruji bagaimana faktor budaya memengaruhi langsung perilaku manusia, yang melahirkan pertanyaan bagaimana unsur-unsur budaya diciptakan, diubah, diadopsi dalam interaksi.

Kecenderungan untuk patuh, mengemukakan bahwa walaupun di antara para ahli psikologi sosial belum sepakat tentang apakah sifat patuh itu merupakan kecenderungan asli, ataukah dalam hal ini kita berhadapan dengan suatu sifat yang diperoleh kemudian ${ }^{8}$.

Lebih lanjut dikatakan kecenderungan untuk meniru termasuk kecenderungan naluriah yang

- Abustam, M. Idrus. 1984. Penyuluhan Pembangunan. Bogor: Institut Pertanian Bogor. Kumpulan Makalah Tidak Diterbitkan

- Rogers, Everett M. 1983. Diffusion of Innovations. Third Edition. New York: The Press A Division of Macmillan Publishing, Co. Smelser, Neil J. 1975. "Theoritical issues of scope and problems" dalam Evans, Robert R. (ed), Reading in Collective Behavior. 2nd edition. Chicago: Rand Mcnally College Publishing Company h.47

Bouman. 1980. Bunga Rampai Sosiologi. Jakarta: P.T. Jambatan h. 18-20 
berubah-ubah dalam masyarakat. G. Tarde menjelaskan bahwa masyarakat itu adalah buah pengaruh hasrat meniru. Dalam sejarah umat manusia memperlihatkan dua golongan, yaitu golongan yang mendapatkan pikiran baru (inventor) dan golongan meniru yang lebih banyak'.

\section{METODE PENELITIAN}

\section{Teknik Pengumpulan Data}

\section{Wawancara}

Cara yang paling umum dilakukan untuk memperoleh informasi dari informan adalah dengan melakukan wawancara. Wawancara yang digunakan dalam penelitian ini adalah wawancara tak berstruktur. Ada dua alasan yang mendasari sehingga dipakai mengapa menggunakan wawancara tak berstruktur. Pertama, oleh karena titik fokus penelitian adalah mencari jawaban apa peran Masjid Nurul Huda dalam menghentikan merokok warga Bone-Bone dan apa yang memengaruhi warga Bone-Bone berhenti merokok

\section{Focus Group Discussion (FGD)}

Salah satu teknik pengumpulan data yang digunakan dalam penelitian ini adalah Focus Group Discussion yang untuk selanjutnya dipakai singkatan FGD. Umumnya pengumpulan data dengan cara FGD dipakai dalam penelitian kualitatif ${ }^{\circ}$. Cara kedua yang dipakai untuk mengumpulkan data ialah dengan menghimpun beberapa orang dari berbagai kalangan, dalam hal ini dipilih tokoh inovator, Idris. Tokoh masyarakat lainnya, dan bertemu antara orang-orang yang pernah merokok, dan yang tidak pernah merokok dalam suatu kancah pertemuan yang disebut focus group discussion. Jumlah peserta pertemuan ini delapan orang, adalah jumlah yang ideal untuk dilakukan. Peserta FGD antara lain, kepala desa, imam masjid, pengurus masjid, tokoh masyarakat dan beberapa bekas perokok. Teknik ini dimaksudkan untuk memperoleh data dari warga Bone-Bone berdasarkan hasil diskusi yang terpusat yang diselenggarakan di Masjid Nurul Huda sesudah shalat Jum'at pada persepsi warga terhadap berhenti merokok. FGD menjadi amat penting dilakukan untuk menghindari pemaknaan yang salah dari peneliti. Sejauh ini pula teknik ini digunakan untuk menarik kesimpulan terhadap makna-makna intersubyektif yang sulit dimaknakan sendiri peneliti.

\section{Observasi}

Observasi adalah pengamatan sistematis terhadap fenomena yang diteliti. Observasi merupakan proses kompleks yang melibatkan interaksi intensif antara peneliti dengan subjek dalam lingkungan tertentu di lapangan, serta dilakukan secara hati-hati, cermat, fokus, dan bersahabat. Dalam rangka ini peneliti berupaya menggunakan teknik pengamatan melalui keikutsertaan (participant observation) sekalipun pada tingkat partisipasi moderat-aktif, bukan partisipasi lengkap (complete participation), di mana peneliti dituntut sepenuhnya berperanserta dalam apa yang dilakukan subyekdi lapangan.

\section{Teknik Analisis Data}

Langkah-langkah yang ditempuh peneliti dalam menganalisis data berdasarkan sumbernya. Data yang terkumpul dianalisis, diinterpretasi dan diuji keabsahannya oleh peneliti sendiri tanpa melibatkan alat tes atau instrumen penelitian yang dirancang sebelum'nya, meskipun telah disiapkan pedoman wawancara agar lebih fokus pada masalah penelitian

\section{TEMUAN PENELITIAN}

Tahun 2000 dan sebelumnya, penduduk dusun Bone-Bone sebagian adalah merokok, dengan berbagai alasan dan pandangan tentang merokok. Beberapa aspek psikologis juga ikut mewarnai alasan mereka seperti merokok itu mempunyai kenikmatan tersendiri, supaya terlihat laki-laki, agar kelihatan jantan, untuk mengusir rasa kedinginan, rasa sepi di kala sendirian, orangtua, ayah dan keluarga melakukannya, apakah di kebun, di sawah atau di rumah.

Mengingat udara yang dingin, bahkan pada saatsaat tertentu sangat dingin, menurut perkiraan orang yang pernah datang ke sana, dinginnya mencapai 5 derajat $\mathrm{C}$ di kampung Bone-Bone. Keadaan ini membuat banyak orang mengusir rasa dinginnya dengan mengambil sebatang rokok dan menyulutnya dengan api sebagai alat penghangat tubuh.

\footnotetext{
'Shadily, Hassan. 1989. Sosiologi: Untuk Masyarakat Indonesia. Cetakan kesembilan. Jakarta: PT. Bina Aksara, h. 145

10 Bungin, Burhan. 2001. Metodologi Penelitian Kualitatif: Aktualisasi Metodologis ke Arah Ragam Varian Kontemporer. Jakarta: PT
} RajaGrafindo Persada, h. 177 


\section{Profil Desa Bone-Bone}

Penamaan Bone-Bone diceriterakan oleh beberapa penduduk yang sudah pada tua saat ini, seperti Lompo usianya 81 tahun dan Sarrang 71 tahun, bahwa keduanya mendapat informasi dari nenek-nenek mereka, yang ia ingat Bone-Bone itu berasal dari sebuah cerita yang mengisahkan bahwa dulu, pada masa agama Islam belum dianut di sini, maksudnya di kampung Bone-Bone, mulai disebarkan oleh parajuru dakwahnya, yang datang pertama kali di sini adalah penyiar agama Islam dari kerajaan Bone. Mereka datang dan mengaku adalah orang dari Bone untuk mengislamkan siapa saja yang ditemuinya.

Penduduk asli mendengar akan ajakan untuk menerima ajaran Islam yang dibawa oleh pendatang tidak begitu saja diterima oleh warga. Dalam kenyataannya tidak mudah mengislamkan penduduk asli 'I aktu itu. Penduduk asli menolak ajaran yang baru saja diajarkan oleh pendatang itu, karena menolak dan berusaha mada sebuah rumah yang kosong yang menurut ceritanya, tempat tidurnya ditaburi dengan sejenis daun Matin (daun yang sangat gataljikakena tubuh manusia).

Orang yang berbaring, orang Bone itu meniduri daun yang gatal itu, merasakan bukan main gatalnya seluruh tubuh orang yang membaringi daun itu. Orang yang merasakan gatal seluruh tubuhnya berusaha untuk mengusir rasa gatal itu, namun ia gagal. Karena semakin digaruk semakin terasa gatalnya, malah ada yang berusaha untuk menceburkan diri di sungai untuk mandi dan berendam air sungai sangat dingin di tengah malam buta. Karena tidak ada cara untuk mengurangi rasa gatal itu, orang Bone itu berpendapat bahwa "tempat tidurnya" orang di kampung ini menolak kita apalagi warga kampungnya. Akhirnya mereka, orang-orang Bone itu, para pendai Islam itu pergi entah ke mana.

Begitulah kisahnya, oleh karena mereka, orang Bone itu datang dengan perilaku yang menyenangkan dan mengajarkan sesuatu berupa aqidah Islam, walaupun penduduk setempat belum menerima Islam saat itu, mereka dihargai dan ditunjukkan rumah tersendiri oleh orang kampung. Oleh karena warga menolak secara halus, dari pada menolak dengan keras. Warga penduduk asli memilih jalan damai, biarlah orang Bone itu pergi tanpa harus ada konflik.
Pada saat orang kampung memperbincangkan rumah yang orang kampung tunjukkan untuk mereka, bahwa orang Bone itu menempati rumah dan dipakai sebagai tempat berda'wah, memberi semacam pengajian tentang Islam saat itu. Dengan demikian rumah yang penghuninya orang Bone penyiar agama Islam, menjadikan orang kampung menunjuk ke seberang arah rumah dan menyebutnya Bone, dan karena selalu dan selalu demikian menyebutnya, akhirnya Bone cukup sekali menjadi Bone-Bone.

Dalam konsep terjadinya sebuah desa sebagai tempat terjadinya kehidupan komunal yang padu (kompak), di mana sebagai tempat berlindungnya penduduk yang mengembangkan kerjasama. Di luar desa, terdapat lapangan atau lahan yang luas dipakai untuk keperluan pertanian, peternakan dan pertemuan. Di samping itu terdapatjugajalan yang menghubngan antara komunitas yang satu dengan komunitas lainnya walaupun dalam bentuk yang sangat sederhana, cukup menjadi petunjuk sebagai jalanan. Dalam wilayah komunitas desa-desa itu terciptalah kemudian tempattempat pemukiman dan desa-desa pedalaman". Selanjutnya "desa" dalam ensiklopedi Indonesia tulisan Hassan Sadaly, dkk. adalah bentuk masyarakat yang bersifat komuniti kecil dengan jumlah penduduk yang biasanya kurang darijumlah penduduk kota. Penduduk desa hidup dari berburu memegang adat istiadat. Lebih jauh desa lahir dalam bentuknya yang sekarang ini, menurut Koentjaraningrat bahwa ciri-ciri masyarakat desa di Indonesia ialah (1) penduduknya hidup dengan bercocok tanam di ladang atau di sawah, (2) masyarakatnya dalam jumlah kecil dan (3) rukun dan tenang, tenteram, seragam, terpencil dan terbelakang ${ }^{12}$. Ketiga ciri yang dikemukakan oleh Koentjaraningrat tadi adalah cocok dengan keadaan di Bone-Bone.

\section{Nenek moyang orang Bone-Bone}

Salukanan dalam sejarahnya yang panjang menunjukkan bahwa penduduk asli belum mengenal Islam. Penduduk asli mengubur mayat orang matinya dengan membawa ke Hang batu di lereng gunung. Keadaan ini mirip dengan cara orang Toraja mengubur mayat seperti yang diajarkan oleh kepercayaan Aluk todolo. Dengan demikian terdapat dugaan yang kuat

" Mattulada, 1994. Linghmgan Hidup Manusia. Jakarta: Pustaka Sinar Harapan, h.35

Koentjaraningrat, 1964. "Isi Konsep 'Desa' di Indonesia" dalam Koentjaraningrat (ed), Masyarakat Desa di Indonesia, (him 346.370). Jakarta: Yayasan Badan Penerbit Fakultas Ekonomi Universitas Indonesia, h. 346 
yang membahayakan. Pada bagian belakang rumah dipergunakan sebagai dapur atap rumah saat ini semuanya terbuat dari seng. Lantai dan dindingnya terbuat dari papan walaupun dalam kenyataannya baru tiga rumah yang dianggap selesai karena dindingnya sudah dibuat sedemikian rupa sehingga tidak terlihat lagi sebagai dinding untuk sementara.

Tipe rumah panggung, saat ini terbuat dari kayu, sebagian memakai kayu ulin, seluruh rumah memakai atap seng, dinding kayu papan seperti rumah panggung pada umumnya. Menurut orang-orang dikatakan bahwa semua rumah yang ada di Bone-Bone belum ada yang jadi, lihatlah dinding rumah-rumah kelihatan masih merupakan susunan dari papan kayu yang dipakai sebagai penghalang angin dan penghangat untuk dingin.

Rumah keci 1 yang terletak di samping rumah induk adalah tempat yang dibangun khusus untuk menyimpan hasil sawah berupa padi disebut dalam bahasa Duri landak. Lumbung padi (landak) adalah bangunan yang mirip atau sama dengan rumah panggung, namun lebih kecil ukurannya dan hanya dipakai untuk menyimpan padi hasil sawah.

Tampak secara jelas bahwa setiap rumah mempunyai rumah kecil yang dipakai sebagai lumbung padi, terletak di samping rumah induk itulah terdapat lumbung padi yang terbuat tiang dan dinding dari kayu dan atapnya seng. Tiangnya yang membedakan dengan lumbung padi yang ada di Toraja. Tiang lumbung padi orang Bone-Bone diambil dari kayu bundar dibiarkan tetap bundar, bukan persegi seperti pada kebanyakan tiang rumah. Dipilih tiang tetap bundar seperti itu dengan anggapan bahwa tikus tidak dapat memanjat naik ke lumbung padijika memakai tiang yang bundar. Ukuran lumbung padi memang kecil hanya sekitar panjang dan lebar 1,5x2 atau 3 meter dengan tinggi kira-kira 2 meter.

Hari Jum'at di desa Bone-Bone semua laki-laki dewasa tidak akan pergi jauh dari rumahnya. Kebiasaan wargayangdemikian ini sudah berlangsung lama, malah diinformasikan oleh warga bahwa sejak pemerintahan dusun, atau kampung. Laki-laki menunda bepergian ke arah agakjauh, dengan alasan karena takut ketinggalan sholat Jum'at berjamaah. Diketahui dari sejumlah informan yang mengemukakan bahwa untuk mencapai kebun kopi mereka butuh waktu sekurang-kurangnya satu hingga 2 jam dengan jalan kaki. Hanya dengan jalan kaki para pekebun kopi dapat mencapai kebun kopinya. Tidak ada kemungkinan atau cara lain, jalan kaki satu-satunya cara untuk sampai ke kebun.
Kuda memang ada satu dua ekor milik warga yang sesungguhnya dapat saja dikendarai oleh pemiliknya. tetapi tidak terlalu biasa dipakai demikian karena kondisi jalanan terjal dan melewati bukit-bukit yang terjal dan berbahaya karena salah satu sisijalan itu adalah tebing yang curam. Kuda hanya dipakai untuk mengangkut beban seperti kopi, padi atau hasil kebun lainnya untuk perjalanan yang singkat dan pendek. Dengan melalui bukit-bukit terjal dan tingkat kemiringan sampai 70 derajat bahwa kebun kopi milik warga rata-rata di atas 4 kilometerjauhnya dari rumah tempat kediamannya.

Setiap Jum'at jam 10 lewat di pagi hari, sudah terjadwal, ibu-ibu datang ke masjidNurul Huda untuk menghadiri tadarus al Qur'an, atau mendengarkan pengaj ian jika ada muballig yang datang. Bone-Bone sebagai desa yang penduduknya taat beribadah dan berusaha menjalankan perintah-perintah syariah. Di masjid Nurul Huda tidak akan terlihat perempuan, tertutup tirai, sekalipun menjalankan ibadah sholat. Itulah sebabnya maka waktu yang digunakan untuk melakukan pengaj ian pada sekitarjam 10 pagi hingga 11 lewat, sebelum laki-laki pada berdatangan untuk sholat Jum'at. Bagaimana dengan uztad laki-laki yang membawakan pengajian pada kaum ibu-ibu, hal itu diperbolehkan karena dianggap bahwa mendengarkan pengajian itu tidak terbatas pada laki-laki atau perempuan saja.

Anak-anak yang usia SD telah memperlihatkan aktivitasnya ke masjid setiap waktu sholat berjamaah sehingga tidak heran jika mereka sejak subuh sudah membiasakan diri untuk sholat berjamaah. Jumlahnya yang datang sholat jemaah subuh lebih 30an anak-anak.

Hari Sabtu bagi warga bone-Bone adalah hari pemerintah. Apa artinya hari pemerintah, hari yang disepakati sejak dahulu, dan kenyataannya dari turun temurun dilakukan warga bahwa hari Sabtu adalah hari dilakukannya hari gotong royong mengerjakan apa saja yang sifatnya tidak untuk kepentingan diri sendiri, keluarga, atau kerabat lainnya. Hari Sabtu mereka mengerjakan pekerjaan yang sifatnya pekerjaan fisik, seperti memperbaiki gorong-gorong untuk saluran air, mengerjakan pembangunan masjid, membuat atau memperbaiki jalan yang rusak seperti menutup kubangan dengan tanah dan batu, akan dikerjakan pada hari Sabtu secara massal.

Kaum Ibu-ibu, pada hari Sabtu, sudah menjadi tradisi sejak pagi hari membuatkan kue tradisional dengan bahan beras ketan hitam ditambah dengan santan kelapa dan gula merah, aren, kemudian dibuat 
bubl-bulat panjang kira-kira $15 \mathrm{~cm}$, dibungkus dengan agung yang sudah dikeringkan. Kue itu dibawa ke lokasi di mana orang-orang bekerja. Tempat bekerjanya warga masyarakat khusus bagi laki-laki Iwsanya di sekitar kampung saja, tidak sampaijauh di Iwrpemukiman warga.

Pada hari Sabtu inilah yang dipakai oleh orang Bone-Bone melaksanakan pembicaraan tidak resmi :- merencanakan kegiatan mingguan untuk "..; na n desanya.

Ftanluduk dan Kehidupan Sosial Ekonomi Desa lah penduduk

" etiap orang yang menempati suatu lokasi tertentu - .. sebagai penduduk.

Tabel 1.

Data Penduduk

Menurut Dusun/Kampung Tempat Tinggal Desa Bone-Bone Tahun 2010

\begin{tabular}{l|c|c|c|}
\hline Dusun/Kampung & Laki-Laki & Perempuan & Juinlah \\
\hline 3-r.vj BUla & 157 & 134 & 291 \\
\hline 3_zgin-Bungin & 173 & 161 & 334 \\
\hline Fecdokesan & 100 & 72 & 172 \\
\hline 3 one-Bone & 430 & 367 & 797 \\
\hline
\end{tabular}

"•tr: Kantor Desa Bone-Bone, 2010

? er.duduk desa Bone-Bone yang terdiri dari laki>ebanyak 430 orang dan perempuan sebanyak 367 sag yang tersebar di 3 dusun/kampung. Kampung

Billa dan kampung Bungin-Bungin hanya -rarai olehjalanan, sedangkan kampung Pendokesan

h Timur yangjaraknya kira-kira 3 kilometer dari hi Desa Bone-Bone.

$r$ er.duduk yang telah berusia dewasa (awal) bagi

- _ raj in membantu orangtuanya di kebun atau di

Dipandang dari segi ekonomi, hampir semua

$r^{\wedge} s h$ tangga di desa menjalankan usaha pertanian dba perkebunan.

\section{$\mathrm{P}: l i$ pemukiman}

Penduduk mendirikan rumah, yang menurut orrg 3one-Bone adalah rumah panggung Bugis, di lahan tar yang cukup untuk menempatkan sebuah ah ukuran yang sederhana, rata-rata 5 meter $x$ er. di area yang berbukit-bukit, dengan tingkat :iringan sekitar 60-70 derajat. Rumah penduduk berdekatan antara rumah yang satu dengan mah lainnya, namun tidak begitu mudah untuk mencapai rumah yang satu dengan rumah lainnya, harus memerlukan waktu yang karena bukannya letaknya saling berjauhan, tetapi karena letak kemiringannya lahan yang ditempati rumah yang satu dengan rumah lainnya. Hampir tidak ada dua rumah yang sejajar pada medan datar yang sama didapatkan di Bone-Bone.

Lahan datar yang paling luas adalah lapangan yang ukurannya tidak lebih dari 50 meter x 80 meter, letaknya di samping masjid Nurul Huda dan di bawah SD Inpres 159 Bone-Bone.

\section{Penganut Islam yang taat}

Seluruh penduduk Bone-Bone beragama Islam. Aktifitas sehari-hari senantiasa menyandarkan pada ajaran Islam yang ketat. Sholatjamah dilakukan secara rutin di waktu Subuh, Magrib dan Isya. Pada saat sholat Dhuhur dan Ashar dilakukan hanya beberapa orang yang kebetulan bekerja di sekitar rumah, dan tidak di kebun kopi miliknya yangjauh-jauh.

Sejak kecil, anak-anak baik laki-laki atau perempuan sudah dilatih untuk datang sholat berjamah pada waktu-waktu di mana mereka ada di kampung. Sholat Subuh secara berjamah, rata-rata sekitar 30an anak laki-laki yang datang ke masjid. Pulang dari masjid sekitar jam 6 pagi, untuk mengaso sebentar, mandi, sarapan kemudian ke sekolah. Mereka sebelum tamat Sekolah Dasar diwajibkan untuk menghapal Juz Amma, yang juga disebut dengan Qur'an kecil.

Anak-anak yang bermain di lapangan, dekat masjid, di waktu di luar jam sekolah, sore hari. Biasanya anak laki-laki tidak berbaur dengan anak perempuan. Masing-masing jenis kelamin bergerombol bermain sendiri-sendiri.

\section{K E S I M P U L A N}

1. Peran masjid Nurul Huda sebagai tempat memulai, merencanakan dan menyebarkann usaha menghentikan kebiasaan merokok warga BoneBone dengan cara:

a. melontarkan Issu, Dusun Bone-Bone akan bebas asap rokok

b. mengorganisir pendukung gagasan

c. membuat kesepakatan: semacam kontrak sosial

d. mengumumkan kesepakatan di masjid, dusun Bone-Bone bebas asap rokok dengan pertimbangan: 
1) Merokok menghambat pendidikan

2) Merokok merusak kesehatan diri sendiri dan orang lain

3) Merokok merupakan hidup boros secara ekonomis

4) Merokok haram hukumnya dalam Islam

2. Response warga masyarakat sebagai sistem penerima terhadap pesan berhenti merokok. Ada warga masyarakat yang merokok, langsung menerima anjuran untuk berhenti merokok. Meskipun sebagian warga masyarakat yang merokok menolak ajakan, himbauan, atau ajaran untuk berhenti merokok. Pada akhirnya, seluruh warga dusun Bone-Bone menerima himbauan, ajakan dan ajaran untuk berhenti merokok.

Ucapan terimakasih kepada Balai Penelitiang dan Pengembangan (Litbang) Agama Makassar yang berkenan memuattulisan ini dalam Jurnal Al-Qalam., Kepala desa Bone-bone, dan warganya yang telah membantu memberikan informasi yang terkait dengan penelitian ini, sehingga penelitian ini dapat dilaksanakan.

\section{DAFTARPUSTAKA}

Ritzer. G dan Goodman, D. J., 2003. Modern Sociological Theory. Edisi Keenam. Terjemahan oleh Alimandan. 2007. Jakarta: Kencana Prenada Media Group

Henslin, James M. 2006. Essentials of Sosiologi: A Down-toEarth Approach. Jilid 1. Edisi 6. Terjemahan oleh Kamanto Sunarto. 2007. Jakarta: Penerbit Erlangga.

Ritzer, G dan Goodman, D. J., 2003. Modern Sociological Theory. Edisi Keenam. Terjemahan oleh Alimandan. 2007. Jakarta: Kencana Prenada Media Group

Ross, Helen S., and Mico, Paul R., 1980. Theory and Practice in Health Education. California: Mayfield Publishing Company.

Abustam, M. Idrus. 1984. Penyuluhan Pembangunan. Bogor: Institut Pertanian Bogor. Kumpulan Makalah Tidak Diterbitkan

Rogers, Everett M, Burge, Rabel J, Korsching, Peter R, dan Donnermeyer, Joseph E, 1988. Social Change in Rural Societies: An Introduction to Rural Sociology. Third Edition. New Jersey: Prentice-Hall, Inc.'

Rogers. Everett M. 1983. Diffusion of Innovations. Third Edition. New York: The Press A Division of Macmillan Publishing, Co.

Smelser. Neil J. 1975. '"Theoritical issues of scope and problems" dalam Evans, Robert R. (ed). Reading in Collective Behav ior. 2nd edition. Chicago: Rand Mcnally College Publishing Company

Smelser. Neil J. 1975. "Theoritical issues of scope and problems" dalam Evans, Robert R. (ed), Reading in Collective Behav- ior. 2nd edition. Chicago: Rand Mcnally College Publishing Company

Bouman. 1980. Bunga Rampai Sosiologi. Jakarta: PT. Jambatan Shadily, Hassan. 1989. Sosiologi: Untuk Masyarakat Indonesia. Cetakan kesembilan. Jakarta: PT. Bina Aksara.

Bungin, Burhan. 2001. Metodologi Penelitian Kualitatif Aktualisasi Metodologis ke Arah Ragam Varian Kontemporer. Jakarta: PT RajaGrafindo Persada.

Koentjaraningrat, 1964. "Isi Konsep 'Desa' di Indonesia'" dalam Koentjaraningrat(ed), Masyarakat Desa di Indonesia, (him 346.370). Jakarta: Yayasan Badan Penerbit Fakultas Ekonomi Universitas Indonesia.

Mattulada, 1994. Lingkungan Hidup Manusia. Jakarta: Pustaka Sinar Harapan. 